\title{
Pola Kepemimpinan Di Pondok Pesantren Dalam Prespektif Milenial
}

\author{
Wafiyatu Maslahah \\ Universitas Sebelas Maret \\ wafiya.maslahah@gmail.com
}

\section{Article History}

received 1/9/2021

revised $1 / 10 / 2021$

accepted 1/11/2021

\begin{abstract}
The research aims to: 1.) determine the role of pesantren in the millennial perspective, and 2.) determine the pattern of leadership in Islamic boarding schools in the millennial perspective. It is interesting to study the development of Islamic boarding schools in the millennial era as a legacy of education during the Islamic era, particularly its role in the millennial perspective and its leadership pattern. The qualitative research method was used in this study. All leaders, caregivers, teachers, residents near the Islamic boarding school, and students at Pondok Pesantren Assalam Jambewangi Selopuro Blitar comprise the research population. Purposive random sampling was used to select the research sample. Interviews, observations, and documentation are used to collect research data. Data triangulation is used to verify the accuracy of the data. This research yielded the following findings is Islamic boarding schools, in their role in the millennial era, can keep up with the times. still exist and are improving. This Islamic Boarding School is a salafiyah that can keep up with the times as well as Science and Technology without departing from the existing guidelines. Without departing from the rules enshrined in Islam's teachings.
\end{abstract}

Keywords: Leadership, Islamic Boarding School, Millennial Perspective

\begin{abstract}
Abstrak
Penelitian ini bertujuan untuk, 1.) mengetahui peran pesantren dalam prespektif milenial, 2.) mengetahui pola kepemimpinan di pondok pesantren dalam prespektif milenial. Pada era milenial di pondok pesantren sebagai warisan pendidikan pada masa Islam menarik untuk diteliti dalam perkembangannya, khususnya peranannya dalam prespektif milenial dan pola kepemimpinannya. Metode dalam penelitian ini yaitu kualitatif. Populasi penelitian yakni seluruh pimpinan, pengasuh, ustadz dan ustadzah, warga disekitar pondok pesantren dan santri di Pondok Pesantren Assalam Jambewangi Selopuro Blitar. Sample penelitian dilakukan dengan teknik pengambilan Purposive Random Sampling. Pengumpulan data penelitian dilakukan dengan wawancara, observasi, dan dokumentasi. Pengecekan keabsahan data di lakukan dengan cara Triangulasi data. Penelitian ini memiliki hasil adalah pesantren dalam peranannya di era milenial yakni mampu mengikuti perkembangan zaman. masih tetap eksis dan bahkan berkembang lebih baik. Pondok Pesantren ini merupakan salafiyah yang mampu mengikuti gerak perkembangan zaman serta IImu Pengetahuan dan Teknologi tanpa meninggalkan pedoman-pedoman yang ada. Tanpa meninggalkan kaidahkaidah yang ada dalam ajaran agama Islam.
\end{abstract}

Kata kunci: Kepemimpinan, Pondok Pesantren, Prespektif Milenial

Social, Humanities, and Education Studies (SHEs): Conference Series https://jurnal.uns.ac.id/shes 


\section{PENDAHULUAN}

Indonesia memiliki beragam suku, budaya dan agama. Salah satu agama yang terbesar di Indonesia yakni Islam. Proses masuk Islam di Nusantara terjadi sekitar tahun 1300 Masehi. Pada perkembangan Islam terdapat pendidikan yang bercorak Islami yakni pendidikan Pondok Pesantren. Pada mulanya sebelum Pondok Pesantren ada, pendalaman agama Islam dilaksanakan di masjid atau surau-surau. Pondok Pesantren merupakan lembaga pendidikan yang mendalami tentang ilmu agama Islam. Berdasarkan Fuadah dan Sanusi (2017:41) menjelaskan bahwa Pondok Pesantren lahir dan tumbuh berkembang di tengah masyarakat untuk memenuhi kebutuhan dalam hal ilmu agama Islam.

Pada masa globalisasi terjadi perubahan secara besar dalam kehidupan manusia. Era 4.0 merupakan masa dimana teknologi berkembang sangat pesat. Era milenial menjadikan manusia terbiasa dengan teknologi, media teknologi dan digital teknologi. Pada perkembangan era milenial ini tentunya memberikan efek dalam kehidupan dan pola fikir masyarakat. Pondok Pesantren sebagai lembaga peninggalan masa Islam yang masih berkembang pada saat ini tentunya memiliki pola yang harus mengimbangi era milenial. Pondok Pesantren harus melakukan modernisasi untuk memenuhi kebutuhan di era milenial ini bagi generasi milenial (Sofiyyah, dkk. 2019:16). Peran pondok pesantren di era Milenial tentunya harus menghadapi tantangan tersebut supaya tidak tergerus oleh perkembangan zaman.

Pada pondok pesantren kepemimpinan dilakukan oleh Kyai. Sebagai pemimpin pondok pesantren Kyai memiliki peranan yang luar biasa. Kepemimpinan merupakan suatu bagian yang penting dalam sebuah lembaga yakni khususnya pondok pesantren. Kepemimpinan merupakan kunci sukses dalam suatu organisasi (Pohan, 2019: 157). Pemimpin memiliki tugas dapat mengorganisasikan dan mengarahkan sumber daya manusia yang ada serta mampu mengembangkan lembaga dengan optimal. Keberhasilan kepemimpinan dilihat dari berkembangnya lembaga yang dikelola serta kepuasan anggota terhadap kepemimpinan tersebut. Pimpinan yang baik pada generasi milenial saat ini menjadi tantangan yang hebat. Pada perkembangan zaman banyak muncul model-model kepemimpinan yang beragam. Pada era milenial pemimpin harus memenuhi syarat-syarat yang kredibel yakni memiliki kemampuan intelektual, visi yang jauh kedepan, selain itu memiliki integritas, kejujuran serta kesetiaan pada kesejahteraan rakyatnya. Kepemimpinan milenial perlu mendukung kemandirian dan jiwa enterpreneurship dalam mendukung kemandirian generasi milenial. Pemimpin di era milenial juga harus melek perkembangan dan teknologi.

Di dalam Pondok Pesantren terdapat generasi milenial yakni santri. Santri merupakan murid-murid yang menimba ilmu kepada Kyai. Santri terdiri dari santri mukim dan non mukim. Santri mukim yakni murid-murid yang berasal dari daerah-daerah yang menetap di pesantren (Hidayat, 2016: 387). Santri mukim tentunya memiliki interaksi sosial yang mendalam dalam kesehariannya di lingkungan Pondok Pesantren. Santri non mukim lebih minim interaksi karena mereka tidak menetap di Pondok Pesantren, hanya menimba ilmu-ilmu saja.

Pada pondok pesantren Assalam Jambewangi merupakan pesantren salaf (tradisional) yang menarik untuk dilakukan penelitian mendalam. Potret pola kepemimpinan Kyai dalam prespektif milenial menarik untuk digali lebih mendalam. Kyai salaf sebagai sosok pemimpin di Pondok Pesantren yang harus menghadapi tantangan zaman digitalisasi dan modernitas yang selalu berdampingan dengan para santri sebagai generasi milenial. Selain itu tentunya juga penting terlebih dahulu menggali peran pondok pesantren dalam prespektif milenial. 


\section{METODE}

Lokasi penelitian dilakukan di Pondok Pesantren Assalam Jambewangi, Kecamatan Selopuro, Kabupaten Blitar Jawa Timur. Pondok Pesantren Assalam Jambewangi terdiri dari santri putra dan putri di dalam satu lokasi tetapi pada bangunan yang berbeda denga diberikan batasan bangunan yang jelas. Penelitian yang dilakukan menggunakan metode penelitian kualitatif. Jenis penelitian yang digunakan yakni deskriptif. Populasi penelitian yaitu seluruh warga masyarakat di dalam dan di lingkungan Pondok Pesantren. Pada penelitian ini menggunakan teknik pengambilan sample dengan cara Purposive Randome Sampling. Sample dipilih secara acak dengan mengambil narasumber yang dianggap penting. Berikut narasumber pada penelitian ini:

1. Pimpinan dan pengasuh di pondok pesantren meliputi Kyai dan Ibu Nyai. Kyai dan Ibu Nyai dipilih dengan alasan beliau yang lebih memahami tentang pondok pesantren. Beliau juga merupakan pendiri pondok pesantren tersebut. Kyai sebagai sosok yang mengetahui tentang kepemimpinan di Pondok Pesantren tersebut.

2. Ustadz-ustadzah merupakan guru-guru yang membantu Kyai dalam proses pembelajaran di pondok pesantren.

3. Santri sebagai generasi milenial dalam hal ini meliputi pengurus (santri senior) yang membantu dan mendampingi santri serta santri junior baik putra dan putri

4. Masyarakat sekitar guna menggali informasi tentang kepemimpinan kyai menurut sudut pandang masyarakat diluar pondok pesantren

Pengambilan data dilakukan dengan wawancara, observasi dan dokumentasi. Pada wawancara dilakukan kepada para informan. Observasi dilakukan untuk mengamati kegiatan di pondok pesantren. Dokumentasi dilakukan untuk mengambil data berupa foto-foto. Proses keabsahan data dilakukan dengan menggunakan Triangulasi Data.

\section{A. Pondok Pesantren}

\section{HASIL DAN PEMBAHASAN}

Pesantren merupakan salah satu lembaga pendidikan tradisional Islam yang sangat tua memiliki perananan yang sangat penting dalam proses perkembangan dan penyebaran Islam di Nusantara (Mu'izzudin dkk. 2019: 44). Pada era globalisasi dan modernisasi pesantren harus mempertahankan eksistensinya.

Menurut Wachid (2013:233-234) bahwa Pondok Pesantren sebagai subkultur yakni bagian budaya yang hidup mandiri, bebas tanpa intervensi, serta tidak berhubungan dengan budaya mainstream. Subkultur yang dimaksud yaitu 1.) pola kepemimpinan di luar kepemimpinan desa dimana pesantren berdiri, 2.) Kitab kuning yang merupakan hasil karya ulama' kuno hingga kini masih dipelajari dan dikaji karena masih sangat sesuai dengan relevansi kehidupan, 3.) Nilai dari pesantren yang terpisah jauh dari nilai masyarakat umum. Pondok Pesantren memiliki otoritas kepemimpinan dan proses pembelajaran tanpa campur tangan pihak-pihak luar. Setiap pondok pesantren memiliki ciri khasnya masing-masing. Pondok Pesantren mampu menjadi roda penggerak dalam kehidupan masyarakat.

Pondok Pesantren merupakan sebuah lembaga pendidikan Islam yang mengakomodir para santri dari berbagai daerah untuk kegiatan mempelajari dan memperdalam ilmu-ilmu agama dibawah bimbingan Kyai (DM, 2013:148). Pondok Pesantren memiliki peranan membimbing para santri dalam memperdalam ilmu-ilmu agama. Santri di dalam pondok pesantren berasal dari berbagai daerah. 
Pondok Pesantren merupakan lembaga Islam tradisional yang berkembang di Indonesia dengan otoritas penuh. Pondok Pesantren merupakan tempat berkumpulkan para santri untuk mengemban ilmu-ilmu agama. Pondok Pesantren mencetak generasi yang memiliki kekuatan serta sikap agamais sesuai dengan nilai-nilai agama Islam.

\section{B. Milenial}

Menurut Peramesti dan Kusmana (2018: 78) generasi milenial memiliki beberapa karakter antara lain, 1.) mampu mengakses teknologi informasi melebihi generasi sebelumnya, 2.) lebih mampu berinovasi dan memiliki keberanian yang tinggi dalam menghadapi tantang, 3.) lebih menyukai kemandirian dan independensi, 4.) menyukai sesuatu yang praktis dan instan. Karakter yang dimiliki oleh generasi milenial perlu difasilitasi tetapi tetap diberikan filter dalam perkembangannya.

Karakteristik generasi milenial berdasarkan Wahana (2015: 18) yakni teknologi dijadikan sebagai gaya hidup atau life style, generasi ini shaltered yaitu terlindungi, bersal dari orang tua yang berpendidikan, memiliki banyak kemampuan atau talenta, kemampuan berbahasa yang beraneka ragam, lebih ekspresif dan eksploratif, memiliki keyakinan yang tinggi, optimis, percaya diri, menginginkan sesuatu yang mudah dan cepat, prestasi merupakan sesuatu yang harus diraih, bekerja dan belajar secara kolaboratif dan berkelompok, mandiri dan terkonsep, mudah dalam mengakses internet dan gadget. Berdasarkan ciri-ciri yang dikemukakan oleh Wahana maka generasi tersebut perlu difasilitasi untuk mengembangkan kemampuan yang dimiliki tetapi tetap diberikan filter dalam prosesnya. Rambu-rambu yang jelas dalam proses pelaksanaannya.

Menurut Hidayat (2018: 68) bahwa terdapat ciri-ciri generasi milenial yaitu sebagai berikut:

1.) Milenial lebih percaya User Generated Content dari pada informasi searah

2.) Generasi milenial lebih mementingkan Handphone dari pada Televisi

3.) Milenial wajib mempuyai media sosial

4.) Milenial kurang suka membaca lebih menyukai melihat sesuatu yang divisualisasikan

5.) Milenial lebih faham teknologi dibandingkan orang tua mereka

6.) Milenial cenderung tidak loyal tetapi bekerja secara efektif

Pemaparan tentang ciri-ciri generasi milenial tersebut menjadikan sesuatu berbasis teknologi, menginginkan sesuatu yang mudah tetapi memperoleh sesuatu yang baik.

Milenial merupakan era dimana manusia tidak asing lagi dengan perkembangan teknologi. Di era milenial teknologi dalam genggaman. Teknologi dijadikan sebagai suatu gaya hidup yang harus dipenuhi. Generasi milenial merupakan generasi yang melek teknologi, memahami teknologi secara cepat dan menggunakannya dalam kehidupan sehari-hari.

\section{Kepemimpinan}

Kepemimpinan merupakan kumpulan dari serangkaian sikap-sikap pribadi yang didalamnya terdapat kewibawaan sehingga dapat dijadikan sebagai sarana meyakinkan anggota yang dipimpin agar mau melaksanakan tugas-tugas yang diberikan dengan ikhlas, tidak terpaksa dan maksimal (Kesuma, 2014:109). Kewibawaan dalam kepemimpinan akan menjadikan anggota segan dan patuh serta melaksanakan tugas dengan penuh semangat dan ikhlas.

Berdasarkan (Paramesti dan Kusmana, 2018: 78), pola kepemimpinan milenial antara lain, 1.) memahami dan menggunakan pola komunikasi generasi milenial yang dipimpin, 2.) kepemimpinan milenial medorong perubahan, kreativitas, dan jiwa wirausaha generasi tersebut, 3.) mendukung kemandirian dan jiwa wirausaha generasi milenial. Pemimpin jika mampu mengayomi generasi milenial maka akan mudah diterima oleh generasi milenial dan menjadi panutan generasi itu. 
Konsep persyaratan kepemimpinan menurut (Kartono, 2014: 32) yakni sebagai berikut:

1.) Kekuasaan yakni kakuatan, otoritas serta legalitas yang memberikan wewenang kepada pemimpin untuk menggerakkan dan mempengaruhi anggotanya dalam melaksanakan sesuatu

2.) Kewibawaan adalah kelebihan, keunggulan dan keutamaan sehingga orang mampu mbawani atau mengatur orang lain sehingga patuh terhadap pimpinan dan bersedia melakukan perintahnya

3.) Kemampuan yakni segala daya, kesanggupan, kekuatan serta kecakapan dalam berbagai hal yang dianggap melebihi kemampuan anggotanya.

Persyaratan sebagai pemimpin menurut pendapat Kartono tersebut akan memudahkan pemipin dalam menjalankan kepemimpinannya dan menjadi panutan bagi anggota dan bawahannya.

Kepemimpinan Kyai menurut Noor (2019:149) memiliki gaya sebagai berikut:

1.) Kepemimpinan religio-paternalistik interaksi antara Kyai dengan para santri dilakukan dengan nilai-nilai agama berdasarkan gaya kepemimpinan Nabi Muhammad SAW.

2.) Kepemimpinan paternalistik-otoriter, paternalistik yakni sebagai bapak yang membimbing para putra putrinya untuk berkreasi, tetapi juga otoriter sebagai pengambil keputusan yang tegas.

3.) Kepemimpinan legal-formal dimana mekanisme kepemimpinan bersifat kelembagaan dimana setiap unsur bekerja sesuai bidangnya dan mewujudkan keutuhan lembaga

4.) Kepemimpinan bercorak alami, dimana setiap kebijakan dilakukan oleh Kyai tanpa campur tangan dari pihak manapun

5.) Kepemimpinan kharismatik-tradisional yakni suatu pola kepemimpinan dengan menganggap sosok yang dianggap memiliki kelebihan dari segi ilmu agama dan pengetahuan, membutuhkan legalitas secara formal, kepemimpinan dilakukan dengan sistem kelembagaan serta memiliki mekanisme yang jelas.

\section{Peran Pesantren Dalam Prespektif Milenial}

Pondok Pesantren Assalam Jambewangi Selopuro Blitar merupakan pondok pesantren yang bercorak salafi atau tradisional. Pesantren salaf menggunakan pembelajaran kitab kuning dengan metode tradisional. Kitab kuning diberi makna dengan menggunakan huruf pegon yakni huruf Arab Jawa. Kitab kuning merupakan kitab yang ditulis menggunakan kertas berwarna kuning. Berisikan materi tentang ajaran agama Islam. Pondok Pesantren memiliki karakteristis yang berbeda dengan sekolah umum yakni unsur pesantren yang terdiri dari Kyai, santri, pondok, kitab kuning dan masjid (Mahdi, 2013:5).

Corak salafi dalam pondok pesantren ini dipertahankan dalam proses pendalaman ilmu agama Islam yakni dengan menggunakan kitab kuning dalam pembelajarannya. Kitab kuning yang diajarkan sangat beragam. Kitab kuning merupakan karya ulama' klasik yang ditulis diatas kertas berwarna kuning berisi ilmu-ilmu keislaman dengan menggunakan huruf Arab (Aliyah 2018: 5-6). Materi yang dikaji dalam pembelajaran di Pondok Pesantren antara lain Fiqih, Nahwu, Hadist, Tafsir, Tauhid dan lain sebagainya. Terdapat pembelajaran kitab kuning yang bersumber dari hasil karya ulama' kuno seperti kitab Ihya' Ulumudin yang ditulis oleh Imam Ghazali. Hasil karya tersebut ditulis sekitar tahun 1100 an Masehi. Sistem pembelajaran yang dilakukan yakni dengan cara memberikan makna pada kitab kuning. Pemberian makna dalam kitab kuning dilakukan dengan memberikan makna berbahasa Jawa dengan menggunakan huruf pegon. Ustadz atau ustadzah merupakan guru yang mendampingi santri dalam proses 
memaknai kitab tersebut kemudian menjelaskan isinya. Peran ustadz dan ustadzah yakni membantu Kyai dalam proses pembelajaran di Pondok Pesantren.

Pada Pondok Pesantren salaf umumnya menggunakan metode pembelajaran berupa sorogan, badongan atau wetonan, dan halaqah (Syafe'i, 2017:66). Sorogan merupakan cara pembelajaran dengan sistem individual yang disimak. Pada sistem ini santri membaca kitab suci (Al-Qur'an) atau membaca kitab kuning dengan disimak oleh ustadz dan ustadzah bahkan Kyai. Sistem pembelajaran wetonan atau badongan merupakan pembelajaran yang di ikuti oleh banyak santri, ustadz dan ustadzah bahkan Kyai membacakan, memaknai atau mengarti dari kitab kuning yang dipelajari. Halaqah yakni model pembelajaran yang diwakilkan kepada santri senior yang dianggap mumpuni disaat ustadz atau ustadzah bahkan Kyai ketika tidak dapat hadir.

Perkembangan era milenial yang berkembang saat ini tentunya membawa dampak dalam peran Pondok Pesantren Assalam Jambewangi dalam prespektif milenial. Pada Pondok Pesantren tersebut dalam menghadapi tantangan di era globalisasi yakni dengan mendirikan sekolah umum yakni meliputi Madrasah Aliyah (MA), Sekolah Menengah Islam Pertama (SMPI) dan Sekolah Menegah Kejuruan Islam (SMKI). Siswasiswi di sekolah umum berbasis pesantren tersebut terdiri dari santri mukim dan santri non mukim. Santri mukim yakni santri yang tinggal dan menetap di Pondok Pesantren. Sedangkan untuk santri non mukim mereka hanya mengaji dan bersekolah saja, tidak menginap dan tinggal di Pondok Pesantren tersebut.

Di Pondok Pesantren Assalam Jambewangi santri mukim secara keseluruhan merupakan generasi milenial. Santri yang hidup berdampingan dengan perkembangan teknologi. Mereka sangat cepat menyerap dan menggunakan teknologi serta memperoleh informasi. Perkembangan teknologi akan memberikan kebermanfaatan kepada setiap generasi salah satunya generasi milenial (W, 2019: 190). Menghadapi hal tersebut Pondok Pesantren memberikan fasilitas kepada para santri berupa perangkat komputer atau laptop dan wifi untuk menunjang kegiatan pada sekolah umum dalam mencari referensi atau tugas dari internet. Akses tersebut diberikan batasan waktu supaya mereka menggunakan fasilitas dengan tepat guna dan tepat sasaran.

Pondok Pesantren ini tentunya tetap memberikan batasan dalam memfasilitasi generasi milenial tersebut yakni salah satu batasannya dilarang membawa dan menggunakan handphone. Kebijakan tersebut dilakukan guna memfilter para santri dari dampak negatif teknologi. Di Pondok Pesantren mereka perlu diberikan batasan tersebut sebagai bentuk tirakat atau menahan hawa nafsu untuk tidak hanya mengejar perkembangan duniawi. Konsentrasi dalam belajar di Pondok Pesantren tetap harus dijunjung tinggi. Batasan demikian diharapkan siswa juga dapat berkonsentrasi dalam belajar dan memperdalam ilmu pengetahuan serta agama.

Peraturan-peraturan yang ada di Pondok Pesantren Assalam Jambewangi juga merupakan hal yang dijadikan pedoman dan rambu-rambu para santri dalam bertingkah laku serta bertindak. Santri sebagai generasi milenial tentunya mereka tetap difasilitasi dalam mengakses ilmu pengetahuan dan teknologi yang berkembang tetapi tetap ada batasan dan pedoman yang jelas yakni berupa perturan yang ada pada Pondok Pesantren. Pada peraturan dijelaskan sangat jelas tentang hal-hal yang boleh dilakukan dan larangan-larangan serta sanksi ketika mereka melakukan pelanggaran.

Pengembangan keterampilan pada santri di Pondok Pesantren Assalam Jambewangi dilakukan guna memupuk kemampuan santri dalam mengembangkan bakat dan minat mereka. Keterampilan yang dikembangkan yaitu qiro'ah. Membaca ayat suci Al-Qur'an dengan lagu atau nada yang indah tetapi tetap memperhatikan mahraj yang tepat. Selain qiro'ah terdapat keterampilan khitobah atau pidato untuk mengasah kemampuan santri dalam berpidato. Nasyid atau shalawatan merupakan kegiatan pengembangan keterampilan santri dalam melagukan sholawat dengan nada-nada yang 
indah. Menulis huruf Arab dengan metode kaligrafi diberikan kepada santri untuk mengembangkan keterampilan dalam menulis huruf Arab yang indah. Pencak Silat Pagar Nusa diberikan untuk santri yang memiliki ketrampilan dalam melindungi diri dan menyalurkan bakat mereka dalam kegiatan fisik yang edukatif.

Selain pengembangan keterampilan tersebut pada Pondok Pesantren Assalam Jambewangi diberikan kegiatan pengembangan berwirausaha. Santri sebagai generasi milenial di latih untuk siap mengadapi tantangan dengan dibekali sikap berwirausaha. Istilah yang sering di kemukanan yakni Santripreneur dimana santri berwirausaha. Pendidikan kewirausahaan santri merupakan suatu usaha yang terencana dilakukan oleh pondok pesantren dalam meningkatkan kemandirian pada para santri (Adawiyah, 2018: 83). Bentuk kegiatan wirausaha santri dilakukan melalui kegiatan pengadaan kantin dan koperasi pondok pesantren. Santri diberikan kesempatan untuk menjadi penjual di kantin atau koperasi tersebut dengan didampingi oleh santri senior (pengurus). Disitu mereka diajak dan diajari cara menentukan harga, cara menjual dan cara menghitung laba dari penjualan. Praktik langsung dalam kewirausahaan tersebut mendorong sikap berwirausaha para santri. Kegiatan ini tidak wajib melainkan santri dapat memilih kegiatan-kegiatan pengembangan keterampilan yang diinginkan.

\section{E. Pola Kepemimpinan di Pondok Pesantren Dalam Prespektif Milenial}

Kepemimpinan pondok pesantren memiliki keunikan yakni menggunakan sistem kepemimpinan tradisional yakni penghormatan terhadap seseorang yang memiliki kelebihan ilmu agama yang tinggi (Arifin, 2016:56). Santri menghormati Kyai tanpa paksaan dari sisi manapun. Sikap tawadhu' santri terhadap Kyai merupakan suatu wujud penghormatan terhadap Kyai untuk mendapatkan barokah dikehidupannya.

Menurut Ibrahim (2014:255) bahwa figur Kyai sebagai pemipin di Pondok Pesantren salaf berperan sebagai penentu dan penjaga eksistensi pesantren, yang merupakan sosok kharismatik yang menjadi panutan santri, pengurus dan masyarakat. Setiap perkataan Kyai merupakan hal yang sakral dan dipatuhi oleh setiap santri atau masyarakat umum. Kharismatik Kyai dalam prespektif milenial masih sangat dijunjung tinggi oleh masyarakat. Pola kepemimpinan Kyai masih dijadikan rujukan di era milenial. Kyai di era milenial semakin sadar akan pentingnya mengikuti perkembangan ilmu pengetahuan umum dan teknologi. Pada Pondok Pesantren Assalam Jambewangi Selopuro Blitar Kyai memiliki keilmuan yang seimbang dari segi ilmu pengetahuan umum dan agama. Dr. KH. Moh. Nadjib, M.Ag, M.Pd. merupakan pendiri sekaligus pengasuh di Pondok Pesantren tersebut. Beliau juga merupakan pegawai negeri sipil di lingkungan Kementrian Agama Kabupaten Blitar. Kyai dijadikan juga sebagai tokoh yang dituakan. Tokoh yang dianggap sebagai pengayom keluarga, penyejuk bagi seluruh santri atau jama'ahnya.

Kepemimpinan di Pondok Pesantren Assalam Jambewangi berdasarkan sistem turun temurun. Gaya kepemimpinan secara turun temurun dimaksudkan bahwa kepemimpinan dipegang oleh anggota keluarga Kyai berdasarkan keturunan (Jariyah, dkk., 2020:128). Di Pondok Pesantren ini dipilih langsung oleh Kyai sebagai penerus pengembangan Pondok Pesantren dan kepemimpinannya. Generasi penerus kepemimpinan disini yakni putra/putri dari Kyai. Sistem kepemimpinan yang dilakukan secara turun temurun dilakukan karena keturunan dianggap sebagai orang yang sangat faham perjuangan Kyai. Keturunan dianggap sebagai orang yang menguasai seluk beluk, proses serta tujuan didirikannya Pondok Pesantren. Dipilihnya keturunan diharapkan dapat mengembangkan cita-cita, visi, serta misi Kyai dalam mengembangkan Pondok Pesantren. Sistem kaderisasi sudah dilakukan Kyai sejak putra-putrinya masih kecil. 
Keunikan yang terjadi dalam proses kaderisasi kepemimpinan di Pondok Pesantren Assalam Jambewangi yakni generasi penerus yang merupakan putra-putri Kyai harus memiliki keseimbangan dalam mendalami ilmu agama dan ilmu pengetahuan umum. Kyai menyadari bahwa semakin berkembang zaman maka keilmuan yang didapatkan harus seimbang. Hal tersebut dilakukan guna mampu berksistensi di berbagai zaman. Khususnya dalam mengahadapi era globalisasi dan era milenial. Keilmuan yang seimbang tersebut dapat menjadikan Pondok Pesantren tetap mampu menjawab berbagai tantangan dan perkembangan zaman. Disini kepemimpinan Kyai di Pondok Pesantren Assalam Jambewangi telah memiliki sikap visioner dalam proses pengembangnya. Menurut Asifudin (2016:365) bahwa manajer ideal dalam pengembangan Pondok Pesantren yakni Kyai yang visioner.

Pola kepemimpinan di Pondok Pesantren Assalam juga sangat mendukung perkembangan generasi milenial. Menurut Indrawati (2014: 81) bahwa kepemimpinan harus menginspirasi dari segi keterampilan, pengetahuan, kerendahan hati dan mampu mengembangkan motivasi anggotanya. Kyai mendukung penuh seluruh santri untuk menempuh pendidikan formal. Seluruh santri di Pondok Pesantren tersebut menempuh pendidikan formal mulai dari tingkat Sekolah Menengah Pertama (SMP) sederajat hingga di Perguruan Tinggi. Dukungan tersebut merupakan bentuk tindakan pemimpin dalam mengadapi Globalisasi dan memfasilitasi santri sebagai generasi milenial untuk memperoleh ilmu pengetahuan dan teknologi yang berkembang. Kyai berharap supaya para santri memiliki kehidupan yang lebih baik dan sukses.

Kepemimpinan Kyai di Era Milenial pada Pondok Pesantren Assalam Jambewangi sangat menjunjung tinggi nilai keikhlasan. Kyai memiliki prinsip bahwa setiap pendapatan lembaga dikembalikan lagi untuk kesejahteraan umat. Difungsikan untuk mengembangkan segala hal yang berhubungan dengan umat. Digunakan untuk mengembangkan sarana dan prasarana pondok pesantren. Kyai tidak menerima imbalan apapun dalam mengembangkan Pondok Pesantren. Keikhlasan Kyai bukan didorong untuk mendapatkan keuntungan tertentu (Suradi, 2018:59). Kyai dan para ustadz ustadzah ikhlas dalam mendidik dan membimbing para santri. Pola keikhlasan dalam kepemimpinan Kyai menjadikan para satri sebagai generasi milenial sangat segan dan bangga dalam memperdalam ilmu-ilmu di Pondok Pesantren tersebut. Jiwa keikhlasan Kyai dan para ustadz serta ustadzah menjadikan panutan santri untuk selalu belajar memperkuat keikhlasan dalam diri mereka.

\section{KESIMPULAN}

Pondok pesantren Assalam Jambewangi merupakan pondok pesantren tradisional Peranan pondok pesantren tersebut berdasarkan prespektif milenial yakni tetap mempertahankan proses pembejarannya menggunakan kitab kuning tradisi pesantren. Pondok pesantren dalam peranannya dipandang dari prespektif milenial yakni mendirikan lembaga-lembaga formal yakni Madrasah Aliyah, Sekolah Menengah Pertama Islam, dan Sekolah Menengah Kejuruan Islam. Santri sebagai generasi milenial diberikan akses untuk mengikuti perkembangan teknologi dengan diberikan fasilitas oleh pondok pesantren, tetapi tetap memperhatikan batasan-batasan pada aturan yang telah ada di pondok pesantren. Generasi milenial di pondok pesantren yakni santri. Para santri diberikan wadah dalam pengembangan keterampilan untuk menghadapi era milenial.

Perkembangan di dalam Pondok Pesantren tidak dapat dari kepemimpinan Kyai sebagai pimpinannya. Kepemimpinan Kyai pada pondok pesantren tersebut mengunakan kepemimpinan tradisional, kharismatik, berdasarkan pengkaderan, turun temurun, inspiratif, dan visioner. Pola kepemimpinan Kyai demikian menjadikan inspirasi 
dan panutan bagi para generasi milenial di pondok pesantren. Demikian para santri menjadi lebih memiliki gambaran dalam bersikap dan bertindak.

\section{DAFTAR PUSTAKA}

Adawiyah, Siti Robiah. (2018). Pendidikan Kewirausahaan di Pesantren Sirojul Huda. Jurnal COMM-UDU. Vol. 1, 81-87.

Aliyah. (2018). Pesantren Tradisional Sebagai Basis Pembelajaran Nahwu dan Sharaf dengan Menggunakan Kitab Kuning. Al-Ta'rib, Jurnal Pendidikan Bahasa Arab dan Kebahasa Araban. Vol. 6, No. 1, 1-25.

Arifin, Zaenal. (2016). Efektifitas Kepemimpinan Lembaga Pendidikan Islam di Pesantren. Tribakti: Pemikiran Keislaman. Vol. 27, No.1, 40-64.

Asifudin, Ahmad Janan. (2016). Manajemen Pendidikan untuk Pesantren. Manageria, Jurnal Manajemen Pendidikan Islam. Vol. 1, No. 2. 355-366.

DM, Herman. (2013). Sejarah Pesantren di Indonesia. Jurnal Al-Ta'dib. Vol.6, No.2, 145158.

Fuadah, Fitriyah Samrotul dan Sanusi, Hary Priatna. (2017). Manajemen Pembelajaran di Pondok Pesantren. Jurnal ISEMA. Vol. 2, No. 2, 40-58.

Hidayat, Andi. (2018). Metode Pendidikan Islam untuk Generasi Milennial. Fenomena: Jurnal Penelitian. Vol. 10, No.1, 55-76.

Hidayat, Mansur. (2016). Model Komunikasi Santri dengan Kyai di Pesantren. Jurnal Komunikasi, ASPIKOM. Vol. 2, No. 6, 385-395.

Ibrahim, Rustami. (2014). Eksistensi Pesantren Salaf di Tengah Arus Pendidikan Modern (Studi Multisitus pada Beberapa Pesantren Salaf di Jawa Tengah). Jurnal Analisa. Vol.1, No.2, 253-263.

Indrawati, Nur Khusniyah. (2014). Management By Inspiration: Implementation Of Transformational Leadership on Bussines at Pondok Pesantren Sunan Derajat. Procedia, Social And Behavioral Sciences. No. 115, 79-90.

Jariyah, Ainun, dkk. (2020). Macam-Macam Model Kepemimpinan di Pesantren. Al Yasini Jurnal Hasil Kajian dan Penelitian Dalam Bidang Kelslaman dan Pendidikan. Vol. 5, No.1, 126-140.

Kartono, Kartini. (2014). Pemimpin dan Kepemimpinan. Jakarta: Grafindo Persada.

Kesuma, Guntur Cahya. 2014. Pesantren dan Kepemimpinan Kyai. Terampil, Jurnal Pendidikan dan Pembelajaran Dasar. Vol.1, No.1, 99-117.

Mahdi, Adnan. (2013). Sejarah dan Peran Pesantren Dalam Pendidikan di Indonesia. Jurnal Islamic Review. Vol.2, No. 1.

Mu'izzudin, Mochammad, dkk. (2019). Implementasi Metode Sorogan dan Bandungan Dalam Meningkatkan Kemampuan Membaca Kitab Kuning. Geneologi PAl: Jurnal Pendidikan Agama Islam. Vol.6, No. 1, 43-50.

Paramesti, Ni Putu Depi Yulia \& Kusmana, Dedi. (2018). Kepemimpinan Ideal Pada Era Generasi Milenial. TRASFORMASI Jurnal Manajemen Pemerintahan. Vol. 10 No. 1, 73-84.

Pohan, Hasril Atieq. (2019). Kepemimpinan di Era Milenial Ditinjau Dari Aspek Komunikasi. Jurnal Komunikasi Islam dan Kehumasan. Vol. 3, No. 2, 156-174.

Sofiyyah, Nilna Azizatus, dkk. (2019). Model Pondok Pesantren di Era Milenial. Belajea: Jurnal Pendidikan Islam. Vol.4, No. 1 1-18.

Suradi, Ahmad. (2018). Dampak Transformasi Sistem Pendidikan Pesantren Terhadap Penanaman Jika Keikhlasan Santri. Jurnal At Ta'dib. Vol. 13, No. 1, 49-66.

Syafe'i, Imam. (2017). Pondok Pesantren: Lembaga Pendidikan Pembentukan Karakter. Al-Tazkiyyah: Jurnal Pendidikan Islam. Vol. 8, No.1, 61-82.

W, R Willya Ahmad, dkk. (2019). Potret Generasi Milenial Pada Era Revolusi Industri 4.0. Focus: Jurnal Pekerjaan Sosial. Vol.2, No.2, 187-197. 
Wachid, Abdurrahman. (2013). Menggerakkan Tradisi. Yogyakarta: LkiS. 